University of Wollongong

Research Online

Faculty of Arts - Papers (Archive)

Faculty of Arts, Social Sciences \& Humanities

$1-6-2001$

\title{
Political jiu-jitsu against Indonesian repression: studying lower-profile nonviolent resistance
}

\author{
Brian Martin \\ University of Wollongong, bmartin@uow.edu.au \\ W. Varney \\ University of Wollongong, wvarney@uow.edu.au \\ Adrian Vickers \\ University of Wollongong, avickers@uow.edu.au
}

Follow this and additional works at: https://ro.uow.edu.au/artspapers

Part of the Arts and Humanities Commons, and the Social and Behavioral Sciences Commons

\section{Recommended Citation}

Martin, Brian; Varney, W.; and Vickers, Adrian, Political jiu-jitsu against Indonesian repression: studying lower-profile nonviolent resistance 2001.

https://ro.uow.edu.au/artspapers/2

Research Online is the open access institutional repository for the University of Wollongong. For further information contact the UOW Library: research-pubs@uow.edu.au 


\title{
Political Jiu-Jitsu Against Indonesian Repression: Studying Lower Profile Nonviolent Resistance
}

\author{
Published in Pacifica Review, Volume 13, Number 2, June 2001, pp. 143-156. The published \\ version incorporates slight subeditorial changes.
}

\author{
Brian Martin, Wendy Varney \\ Science, Technology and Society, University of Wollongong \\ and Adrian Vickers \\ History and Politics, University of Wollongong \\ Contact: \\ Brian Martin \\ Wendy Varney \\ Adrian Vickers \\ Go to: \\ Brian Martin's publications on peace and nonviolence \\ Brian Martin's web site
}

\begin{abstract}
Most case studies of nonviolent action have focussed on prominent instances of open resistance to repression, especially successful resistance. Additional insight into the dynamics of nonviolent action can be gained by studying cases when resistance has been less widespread, less visible or less effective. The value of looking at such cases is illustrated by an examination of the toppling of Indonesian President Suharto in 1998 -- a prominent and successful exercise of nonviolent action -- and, for comparison, the Indonesian anticommunist massacres from 1965-1966 and repression in East Timor in the decade from 1975, two cases where nonviolent resistance was less visible and less effective. These cases reaffirm the crucial role of political jiu-jitsu, namely the process by which repression can stimulate greater support for the resistance.
\end{abstract}

\section{Introduction}

There is a considerable literature on the politics of nonviolent action, showing how methods such as 
leafletting, rallies, vigils, refusals to obey, strikes, boycotts, sit-ins and setting up alternative institutions can be used to oppose repression and aggression and to promote social justice.[1] Using examples or case studies is a standard part of many writings on nonviolent action, which include, for example, examinations of the 1930 salt march led by Gandhi in India,[2] the toppling in 1944 of the dictatorship in El Salvador,[3] the intifada of 1987-1993 against Israeli occupation of Palestine,[4] and the collapse of apartheid in South Africa.[5]

There is much to be gained by studying case studies, including an appreciation of the dynamics of nonviolent action in practice and the importance of various local factors and circumstances. By assessing and comparing a large number of examples, generalisations can be proposed and subsequently tested.[6] Dealing with case studies helps overcome the risk of nonviolence theory becoming divorced from the realities of action.

Most of the case studies in the nonviolence literature deal with action that is public and prominent. Furthermore, there is an emphasis on cases in which nonviolent action is clearly successful in bringing about change. Once a framework for analysing nonviolent action is established, there is a tendency to select case studies that fit the expected pattern. Students of nonviolent action may search all sorts of instances of political action looking for those events that fit the standard model. As a result, other sorts of events, that might provide additional insights or challenges to the standard model, may be overlooked. In the examination of particular cases, aspects that do not fit expectations may be ignored or downplayed. A typical problem is pulling an example of a particular tactic -- such as a boycott -- out of its wider social context and touting it as showing what can be achieved using nonviolent action.

For instance, a favourite example in the nonviolence literature is the collapse of the Kapp Putsch, an attempted military takeover in Germany in 1920.[7] The nonviolent resistance, most prominent in Berlin, was undoubtedly highly significant. It included a general strike, rallies and refusals to obey, down to the detail that bank officials refused to honour cheques written by the coup leaders without proper authorisation, with no government official agreeing to sign the cheques. However, seldom mentioned in the nonviolence literature is the role of armed workers' groups in opposing the putsch as well as seeking social revolution, and the role of the army, which had stood at the sidelines during the right-wing putsch, in smashing the left-wing workers' opposition, including the ongoing general strike in Berlin.[8]

Studying nonviolent action potentially has several purposes, including:

- an intellectual purpose: gaining knowledge into the origins, operation and impacts of nonviolent action;

- a practical purpose: learning how to make nonviolent action more effective;

- an inspirational purpose: motivating people to undertake nonviolent action.

Often, in practice, these purposes cannot be easily separated.[9] Nevertheless, being aware of these different purposes is useful. Nonviolence researchers and activists often search out instances of successful nonviolent action partly because of their inspirational value. Studying nonviolent actions that failed or cases where there was little visible action has less potential to provide inspiration. Yet potentially there is much to learn, both intellectually and practically, through examining such instances.

Our aim in this paper is to demonstrate the value of studying cases where nonviolent action is less prominent or less effective, as a means for learning about the dynamics of nonviolent action. We do this by examining the role of political jiu-jitsu in both high and low-profile resistance to repression. Our general case study is the repressive Indonesian regime under Suharto, 1965-1998. We begin by summarising the events that led to Suharto's resignation in 1998, a case study in prominent and fairly successful nonviolent action. This case study is of interest in itself and lays the ground for a 
comparison with two episodes characterised by less visible and less effective nonviolent action against Indonesian repression: the 1965-1966 massacres and the 1975 invasion and occupation of East Timor.

Out of the many ideas and important contributions to nonviolence theory,[10] we have chosen to focus on the concept of political jiu-jitsu. Richard Gregg in his classic book The Power of Nonviolence introduced the idea of 'moral jiu-jitsu' as a mode of operation of nonviolent resistance. [11] Gregg said that when a person uses physical violence against another individual, to respond with violence is to tacitly agree that violence is an appropriate means of action. A refusal to use violence causes the attacker to lose moral balance, rather like jiu-jitsu causes an attacker to lose physical balance. The presence of onlookers can increase the potency of this effect. Gregg uses the example of strikers who, if they initiate any violence, lose public sympathy. According to Gregg, 'Violence which is not opposed by violence, but by courageous nonviolence, if it is in the open, is sure sooner or later to react against the attacker.'[12]

Gene Sharp revised Gregg's concept of moral jiu-jitsu and adopted the expression 'political jiu-jitsu' to move the focus beyond psychological dimensions. Sharp is widely acknowledged as the world's leading nonviolence researcher.[13] His contributions include a classification of types of nonviolent action, enumeration of hundreds of methods of nonviolent action, collection of a vast amount of illustrative case material, development of the consent theory of power to underpin an analysis of nonviolent action, and an exposition of the dynamics of nonviolent action.

In Sharp's framework, political jiu-jitsu is a key factor in the dynamics of nonviolent action, namely how nonviolent action works. Sharp presents several components: laying the groundwork for nonviolent action; making challenges, which usually brings on repression; building solidarity and discipline to oppose repression; building support through political jiu-jitsu; achieving success by conversion, accommodation or nonviolent coercion; and redistributing power.[14] Sharp describes political jiu-jitsu as follows:

Political jiu-jitsu is one of the special processes by which nonviolent action deals with violent repression. By combining nonviolent discipline with solidarity and persistence in struggle, the nonviolent actionists cause the violence of the opponent's repression to be exposed in the worst possible light. This, in turn, may lead to shifts in opinion and then to shifts in power relationships favorable to the nonviolent group. These shifts result from withdrawal of support for the opponent and the grant of support to the nonviolent actionists.[15]

In essence, political jiu-jitsu uses the opponent's violence to build greater support. For this to work, nonviolent activists must take enough action to significantly challenge the opponent and then be able to maintain nonviolent discipline in the face of repression. If the resisters use violence, then repression is more easily justified and it becomes much more difficult to mobilise support.

According to Sharp, three types of groups can be affected by political jiu-jitsu. The first is uncommitted third parties. For example, in the 1960 Sharpeville massacre, South African police fired into a large crowd of nonviolent protesters without warning, causing many deaths, after some of them began throwing stones. This disproportionate response generated outrage internationally and was a major setback for the South African apartheid regime. The second type of group is the opponent's own camp. For example, adherence to nonviolence in struggles led by Gandhi against British colonial rule in India led to considerable dissent within Britain itself. In contrast, brutal British colonial policies against the more violent Mau Mau rebellion in Kenya generated relatively little opposition within Britain. The third type of group affected by political jiu-jitsu is the resistance movement itself. An example is the massacre of hundreds of peaceful protesters on 9 January 1905 by the government of Russia, which undermined popular support for the Tsar and greatly increased support for revolutionaries. Many more examples of political jiu-jitsu could be cited from a variety 
of contexts, such as the bombing of Greenpeace's vessel Rainbow Warrior by French secret agents, an act that mobilised tremendous sympathy and support for Greenpeace.

However, one aspect of political jiu-jitsu is undeveloped in Sharp's analysis: the presence of a sympathetic audience. In order to generate 'shifts in opinion' and 'shifts in power relationships', the nonviolent action and repression must be visible to an audience that is potentially swayed to support the resisters. We will find, in examining cases in the history of Indonesian repression, getting information to a sympathetic audience makes an enormous difference to the effectiveness of political jiu-jitsu.

In this paper we find evidence that the key dynamic of political jiu-jitsu is just as crucial -- by its absence -- in lower profile and less successful nonviolent resistance as it is by its presence in higher profile and more successful nonviolent action. If this is so, it suggests that a vast number of struggles -- namely the lower profile ones that normally receive much less attention than prominent and successful struggles -- can serve as fruitful areas for investigation of the dynamics of nonviolent action.

\section{The Toppling of Suharto[16]}

Indonesia became a Dutch colony through a long period of expansion beginning in 1619 and ending in the 1920s. After occupation by the Japanese during World War II, nationalist leaders declared independence in 1945 and after a national revolution gained sovereignty in 1949. Over the period 1965-1967, the left-leaning Sukarno government was replaced by a military-dominated regime led by Suharto, accompanied by a major bloodbath, as described in the next section.

The foundation of the Suharto regime's power was the military forces, but with a democratic facade. Within this framework, Suharto maintained power through astute political manoeuvring.[17] He sidelined challengers, rewarded friends (especially family members) and repressed dissent. Repression was systematic: all potential opponents, both popular and in the elite, including the military, were crushed. All organisations that might provide a basis for questioning or challenging the regime, such as political parties, trade unions and cultural bodies, were banned, restrained or brought into the state mechanism, a process called 'depoliticisation.'

As a method to prevent challenges to the regime, repression was supplemented by cooption. The most effective form of cooption was through economic growth, which proceeded at an impressive $7 \%$ annually from 1970. During this time the regime was supported by Western governments and the major international funding agencies and praised for its economic policies.[18]

With the announcement of a period of 'openness' in the late 1980s, voices of dissent began to emerge, but no one inside or outside the country believed that Suharto's grip on power was weakening. Into the mid 1990s, popular opposition was muted, partially as a result of continued economic growth. Opposition political parties were banned or severely constrained, serving only as fig-leaves for a pretend democracy. The regime and its policies were feted by Western governments. The Indonesian military retained ultimate power and received weapons and training from various governments such as Australia and the US.

This suddenly changed as a result of economic collapse, triggered by the crash in Thailand beginning in 1997 which spread to several southeast Asian economies. Indonesia was particularly hard hit, with the collapse of the rupiah leading to widespread impoverishment, more extreme than in other countries.[19] Prior to the collapse, Indonesia's economic policies had been fully supported by the World Bank, the International Monetary Fund and most commentators, but afterwards blame was placed either on corruption and cronyism or on global markets. 
The dramatic change in economic climate opened the doors for a deeper expression of popular opposition. Outrage over corruption, collusion and cronyism became a rallying cry, with the government blamed for economic misfortunes. The regime was not well structured to deal with this new situation. Suharto had become increasingly out of touch with everyday realities since he was surrounded with sycophants, operated using a 1960s way of thinking (including a Cold-War fear of communism) and was tied into the crony system he had used to build his power. As a result, his political judgement suffered. In addition, his health was poor, so both physically and mentally he was not ready for the unprecedented challenges he faced in 1998.[20]

The economic crisis had the most severe impact on the urban working class and the unemployed, but these groups did not take much action, being preoccupied with pure survival. The overt opposition was drawn primarily from the middle classes, including students, academics, university graduates, journalists, lawyers, artists and NGO staff. This middle-class group, having grown up in a time of prosperity, was particularly affected by the sharp changes in lifestyle brought about by the crisis. Of those involved, students were by far the most vocal.

Before 1997, NGO leaders and former student activists had tried to create a coalition in opposition to the regime, but had not got very far: Suharto's methods of depoliticisation were too effective.[21] The collapse of the economy served as a catalyst and a rallying point for a more solidified and organised opposition.

Students began to openly challenge the government by holding rallies on campus and then moving off campus in defiance of conditions imposed by the police. As the rallies became larger, more students joined in and leaders became bolder. Meanwhile, opposition activity blossomed in a range of areas, such as the arts scene. On 12 May 1998, four students and two others in the crowd were killed by troops at Trisakti University, an elite private institution in Jakarta. This event triggered massive rioting and looting in Jakarta, causing extensive damage and leaving more than a thousand people dead (principally looters caught in fires). This event caused a loss of public faith in the regime and led some military elites to think that Suharto should resign in order to placate the population.[22]

Thus, violence by the regime triggered much greater support for the resistance, an example of political jiu-jitsu. Massive rallies were held throughout the country. In Jakarta, students continued to lead protests, which involved ever larger sectors of the population. This unprecedented public display of opposition caused splits within the ruling elite.

Not long before these events, Suharto had promoted his son-in-law Subianto Prabowo to head the Kopassus special force. A ruthless operator, Prabowo had ambitions to gain power over the head of the armed forces, General Wiranto, who was also close to Suharto. Earlier in 1998, various activists 'disappeared,' some of them emerging weeks or months later after imprisonment and torture in secret locations. Others were presumed to have been murdered; their relatives still do not know their fate. This repressive operation was probably orchestrated by Prabowo. He sought to stop student protests by force and was responsible for the killing of students on 12 May, which may have been done purposely by military units rather than accidentally in general shooting.[23] Since this repressive approach was triggering ever more massive popular opposition, some members of the elite decided Suharto had to go.[24]

A student occupation of parliament was crucial. This occupation reached its climax on 20 May and was a key factor in convincing members of cabinet that Suharto had to resign. As the protest expanded, opposition political leaders joined in. Amien Rais, a leading Islamic political figure, called a rally for 20 May. In order to stop it, Indonesian troops shut down central Jakarta. This in turn alienated the business sector, supplying yet more pressure for change. The end was near when the leader of the parliament -- all of whose members were virtually handpicked by Suharto -- called for Suharto to step down. On 21 May Suharto suddenly announced his resignation and his deputy, B. 
J. Habibie, took over. The surprise resignation reduced the chance of a broader democratisation at that time.

The Indonesian events fit a standard pattern of political jiu-jitsu, in which open defiance of the regime generates greater support. If the regime does nothing, then opponents become bolder in their actions. If the regime responds with overt violence, this causes public outrage and greater support for the opposition, though this is not a guarantee of success. It only remains to note a few points of special interest in this case.

One of the standard methods used by the regime to maintain control was to infiltrate potential opposition groups and to foster dissension, such as by accentuating religious and ethnic divisions. Eventually, students attempted to overcome this by instituting tight internal discipline, to the extent of allowing only students to take part in student-organised occupations, in order to prevent infiltration and to maintain focus on a single goal: to get rid of Suharto.

The tactics used by one key student group, Forum Kota (City Forum) illustrate one method of avoiding cooption. Every week this student group changed both its leader and its command post so that no one leader or campus could gain control and be open to cooption.[25] Although the military did try, as usual, to infiltrate the student groups, this proved unsuccessful. One student said laughingly of those who attempted to infiltrate 'They always have short hair and they are in good physical condition. You can spot them a mile away.'[26]

Communication was crucial in coordinating resistance and alerting people to what was occurring. Electronic mail and the web were effective tools for the opposition, since they by-passed censorship of the mass media and were low cost.[27] The editor of the Jakarta Post noted that the protests allowed his newspaper to cover issues that were otherwise strictly forbidden.[28] For their part, members of the Alliance of Independent Journalists gave the students crash courses in how to publish newsletters and convey their ideas.[29]

Open use of violence by the regime, especially the killing of students at an elite university, turned out to be very counterproductive: this was a prime example of political jiu-jitsu in action. In comparison, the 'disappearances' earlier in the year caused far less outrage. The main difference was that it was harder to assign responsibility for covert torture and killing. Similarly, the regime attempted to distance itself from responsibility by using agents provocateurs, paid demonstrators, gangs and criminals to undertake looting, arson and rape, including attacks on the Chinese minority, designed to aggravate ethnic tensions and reduce the chance of unified opposition to the regime.[30] In these cases, the regime attempted to nullify political jiu-jitsu by obscuring its role in violence.

Throughout the events, foreign governments played little overt role and certainly did little to help the opposition. Public events were reported to the world but the outcome was mainly determined by internal dynamics, especially in Jakarta. However, reports of actions on the web and CNN helped the students to maintain their momentum.

\section{The 1965-1966 Massacres[31]}

President Sukarno, leader of the government that came to power following Indonesian independence in 1949, rose to prominence on an anti-colonial platform. He sponsored the development of an alternative 'Third World' through the 1955 Bandung conference and was quick to invoke antiforeign feeling when faced with what he perceived to be continuing colonialist tendencies of large Western states. He showed himself willing to court the Soviet and Chinese governments if it suited him to do business with them rather than the West. The US government[32] felt that the Sukarno government could not be relied upon in a region it considered to be of utmost strategic importance 
and was desperate for a more staunchly anti-communist regime to rule in the archipelago.

The opportunity for change came in 1965 following an attempted coup.[33] The incident deeply tarnished Sukarno's reputation and heralded a power shift towards the military. Along with his military supporters, General Suharto, the Commander of the Jakarta garrison that defeated the coup, took the opportunity to massacre those who were known, thought or rumoured to be members of the Communist Party of Indonesia (PKI) or their sympathisers and many more as well. Using a well orchestrated media campaign, Suharto banned the PKI and escalated his programme of slaughtering communists and suspects. The army systematically went about the obliteration of those deemed politically undesirable in Central Java, moving east through to Bali. As well as killing suspected Communists themselves, army officers gave lists of names to right-wing Muslim groups and other anti-communist militias who were provided with arms and transport for the purposes of carrying out this pogrom. The CIA was firmly behind Suharto's actions, supplying lists of leading communists who had infiltrated various government and military bodies.[34] Although most of the deaths occurred in 1965 and 1966, the slaughter continued until 1969 when virtually all apparent opposition had been eliminated.

Against this wave of killings, left-wing opponents were quickly rendered few and disorganised. Power shifted further to Suharto in March 1966 when the army insisted that Sukarno delegate extensive powers to Suharto, at the time Chief of Staff of the Army, and then officially in 1968 when Suharto was appointed to the presidency in his own right. By then he had set up the conditions for comfortable rule with the bulk of his opponents killed or imprisoned. It is commonly estimated that 500,000 to one million died in his army's anti-communist rampages, making this one of the century's major bloodbaths.[35] At least 400,000 were imprisoned, many on the remote island of Buru.

While many Indonesians struggled against the repressive Suharto power grab, they did so at enormous cost. Many chose not to act because the risks were too great: even the slightest resistance was dangerous and could mean the death of oneself or one's family. Overt resistance would have required not only extraordinary courage but, to be effective, high and efficient levels of organisation would have had to be developed for the new circumstances which prevailed. This would have been a daunting challenge given the number of activists being killed. However, examples of individual bravery exist. For example, the then head of Denpasar Hospital, Dr Djelantik, at great personal risk refused killing squads access to his patients.[36]

Early stages of the dynamics of nonviolent action include laying the groundwork, challenging the opponent and maintaining solidarity and discipline to oppose the resulting repression. In the circumstances of the massacres, these stages were undeveloped to say the least. Nevertheless, the process of political jiu-jitsu could have still operated if the massacres had generated opposition to the regime, either among those potentially targeted, in Suharto's camp or among third parties. Within Indonesia, due to lack of preparation and the disarray caused by the massacres, resistance was limited. However, this need not have applied to third parties. In particular, the massacres could have led to international action either by governments or by nongovernment groups.

As hundreds or thousands were killed every day, Western governments had good information about what was happening. Documents from the period show that Australian and US governments knew about the massacres as they were occurring, yet did nothing to stop them, instead welcoming the elimination of the communist threat.[37] Australian Prime Minister Harold Holt was obviously pleased with the situation in Indonesia when he announced in 1966 that 'with 500,000 to 1,000,000 Communist sympathizers knocked off, I think it is safe to assume a reorientation has taken place.'[38]

There was no groundswell of international public opinion that might have forced governments to adopt a different approach. Perhaps the strongest barrier to more widespread mobilisation was the Cold War paradigm within which many people understood the global order. The beneficiaries of this 
ideology were arms manufacturers and those who sought to invest in repressive regimes such as Indonesia which, if nothing else, seemed politically stable as well as obviously friendly to foreign investment.

However, many people in these Western countries did not perceive the situation in this economic light, nor did they understand the relevance of these economic arrangements. Many simply perceived the world situation as one of danger with the overwhelming need being to hold communism at bay. There was widespread paranoia about the march of communism, widely supported by government propaganda that took advantage of much of the pain and loss from the previous world war.

Belief in the so-called domino effect promoted fear that the march south of communism was almost inevitable except by means of the utmost vigilance, enormous expenditure on arms and inclusion within a nuclear umbrella. With communism having established itself in Eastern Europe and having 'spread' from the Soviet Union to China and Korea, it was a common belief that Indonesia and then Australia (probably by invasion) were next in line. Crude though this was, it held much sway in a fiercely paranoid and anti-communist climate, used by Western governments to control domestic situations as well as to guide foreign policy. During the 1960s and 1970s, the most visible manifestation of the anti-communist impulse was the war in Vietnam.

The media's commitment to anti-communism meant that the government line went largely unchallenged. For their part, opposition political parties usually spent more time supporting the ideology and trying to distance themselves as much as possible from any socialist taint than trying to challenge Cold War assumptions. The barrier of anti-communist ideology proved too large, in the case of the 1965-1966 massacres, to have sufficient pressures mounted on governments to take strong stands against the Indonesian government’s brutality and repression.

Thus, the massacres proceeded without much resulting backlash. Within Indonesia, this can be explained by the lack of preparation for resistance and lack of an organised movement to build on outrage caused by the killings. Outside Indonesia, the massacres received relatively little attention, with anti-communism providing a framework for justifying what was happening. This has been called a case of 'constructive terror', namely mass killing that fostered a favourable investment climate.[39] In terms of nonviolence theory, political jiu-jitsu was rendered ineffective because there was no sympathetic audience that could be readily mobilised as a result of the killings.

\section{East Timor[40]}

East Timor became a Portuguese colony in the 1500s. Prior to that it had been a series of small kingdoms. East Timor remained Portuguese until 1975, shortly after the Caetano regime in Lisbon was overthrown by a coup, bringing about a policy change towards decolonisation. In response several political parties formed in East Timor with views about what sort of future the territory should have. Fretilin was the party that went on to gather most popular support and that was paramount in the struggle for independence.

Following the Lisbon coup, the Portuguese stayed in East Timor until one of the East Timorese parties, the Uniao Democratica Timorense (UDT) staged a small and unsuccessful coup that was fairly easily put down. At that stage the Portuguese retreated to the island of Atauro, thus leaving a temporary vacuum, of which the Indonesian government was keen to take advantage despite Fretilin declaring independence for the Democratic Republic of East Timor in November 1975. Both the Indonesian and Australian governments promoted the view that Fretilin was Marxist.

Indonesian forces invaded in December. As well as military operations, they engaged in massive killing of civilians, rape, torture and destruction. Fretilin was the target of much of the slaughter, 
although the group held its own initially, having its major strongholds in the mountains and being in possession of a substantial number of arms that the Portuguese had left behind. However the Indonesian military slaughter of East Timorese people was so great that it decimated Fretilin forces as part of its overall culling. Fretilin later made a resurgence in small and then greater numbers.[41]

The Indonesian military assault against East Timor left the small territory devastated. Some estimates claim that up to one-third of the population died. Agricultural output fell by almost 70 percent in just three years, causing serious famine. Infant mortality was elevated to among the highest in the world, nearly all East Timorese teachers were executed and 400 schools destroyed.[42]

The Indonesian invasion was largely undertaken with the condonation of Western governments, if not their blessing.[43] The Australian and US governments provided quiet succour, hinting only that they did not wish to be seen as openly supporting or condoning any such invasion. Suharto obliged by forestalling a full-scale invasion until President Gerald Ford and Secretary of State Henry Kissinger had completed a visit they were making to Jakarta.[44]

In Australia, both Liberal and Labor governments adopted the same policies toward Indonesia. Liberal Prime Minister John Gorton visited Indonesia during his term (1968-1971) and Liberal Prime Minister William McMahon (1971-1972) received Suharto as his guest in Australia in 1972. In 1968, immediately after becoming leader of the Australian Labor Party (then in opposition), Gough Whitlam advocated a friendly and supportive approach to the Suharto regime which he suggested was preferable to a communist government which he felt had nearly been in command there.[45] Richard Walsh and George Munster claim that Whitlam had an image of Indonesia that had little to do with reality but more to do with his desire for good relations. Wanting to be sophisticated, cultured and contemptuous of the White Australia Policy which had tarnished Australia's reputation in Asia, Whitlam was keen for a new and close relationship with the neighbour to the north but this meant believing the regime to be more innocuous and somewhat different than it was.[46] As Australian prime minister in September 1975, Whitlam announced that an independent East Timor was not viable, a statement that Suharto would have interpreted as a justification for an invasion.

The Indonesian invasion of East Timor just three months later was in contradiction of the Indonesian government's own prior claim that it had no interest in the territory. Yet the assault should not have been surprising, for intelligence reports available to both Australian and US agencies in 1975 indicated that invasion was precisely the Indonesia government's intention. In 1974, East Timorese spokesperson Jose Ramos Horta had visited Australia, trying to alert the government and any interested groups of the Indonesian military's aggressive intent. Though his warning was received sympathetically by non-government groups, the Australian government paid it no heed.

East Timor solidarity campaigns were started around the world. Activists struggled long and hard to stop the bloodshed and pursued various campaigns such as against Western arms sales to Indonesia. [47] Symbolic actions were used in an attempt to alert other citizens to the situation in East Timor and to take a stand against Western governments' military involvement. In an attempt to 'disturb consciences,' one British activist conducted a peaceful raid on British Aerospace where he hung a banner, painted slogans and hammered the machines of destruction. Conducting his own defence at his resulting trial, he focussed on Britain's supply of this weaponry to Indonesia and its role in the repression of East Timorese.[48] Some time later four women undertook a similar raid of a British Aerospace plant, attacking with household hammers a Hawk fighter aircraft destined for Indonesia the following day and leaving in the pilot's seat a videotaped explanation of their actions.[49]

In Australia the Campaign for an Independent East Timor (CIET) was established in November 1974.[50] Campaign activists in CIET issued press releases warning of the threat of invasion, contacted members of parliament, met with Fretilin activists, sought trade union actions, organised demonstrations, gathered information, put out fortnightly bulletins, fed information to the media, arranged interviews between Australian media and Fretilin spokespeople and encouraged formation 
of East Timor solidarity groups in other countries. Perhaps one of the group's biggest contributions was helping set up secret radio contact in Darwin with Fretilin in East Timor and providing operators and technical support. Several times Australian security police tracked down and seized the transmitter.[51]

According to Denis Freney of CIET, ‘ $\ldots$ despite the best efforts of many people around the country [Australia] to get the government to stop supporting Suharto we had little success, although we were able to keep the question alive even while most people thought it a "lost cause".'[52]

There are several reasons why political jiu-jitsu did not operate effectively in East Timor in the years immediately following the invasion. First, the resistance was not entirely nonviolent. There was nonviolent resistance, to be sure, but this was overshadowed by the guerrilla struggle waged by Fretilin. Arguably, much greater support could have been generated, especially internationally, by an entirely nonviolent resistance. In the 1980s, the East Timorese resistance reorganised to gain more support, with the aim of building unity in East Timor and gaining support in Indonesia and internationally. The new emphasis was on nonviolent action, urban participation and orientation of guerrillas to defending against attacks and not initiating violence. This resulted in a much more potent resistance movement.[53]

Another obstacle to triggering political jiu-jitsu was lack of information about massacres for international audiences. The Indonesian occupiers did everything possible to shut down communication outside the country. The importance of communication to outside audiences can be illustrated by a couple of examples. In 1989, the Indonesian government 'opened' East Timor to outside contact. In November 1991 a slaughter of more than 200 peaceful protesters at the Santa Cruz cemetary in Dili, the capital of East Timor,[54] was recorded on videotape by a Western journalist with the pseudonym Max Stahl, who was able to smuggle it out of the country. When this footage reached an international television audience, it caused outrage and triggered a great increase in Western popular support for the East Timorese struggle[55] -- a classic example of political jiujitsu.

Eventually public sentiment abroad turned against the Indonesian regime, largely as a result of getting more information about events in East Timor than governments were willing to disseminate through formal channels. Following the UN-supervised vote in East Timor in September 1999, in which nearly $80 \%$ of voters supported independence, the Indonesian military in East Timor connived with anti-independence militias in a ruthless orgy of killing and forced relocation. Because much of this occurred in the full spotlight of the world media (at least for those countries where East Timor is considered significant, especially Australia), large numbers of people outside Indonesia were horrified and outraged, leading to many forms of nonviolent action including trade union bans and discouragement of tourism.

Note that in both the 1991 Dili massacre and the 1999 post-vote violence, the East Timorese resistance had by that stage adopted a largely nonviolent approach, Indonesian repression was exercised against nonviolent civilians and information was available to an international audience. Thus, conditions were more conducive to political jiu-jitsu than in the decade from 1975. Of course, other factors played a role, including the saliency of anti-communism, the strength of international human rights and solidarity groups and the interest of the mass media.

\section{Conclusion}

The protests in Indonesia in 1998 that led to the resignation of President Suharto fit the standard pattern of nonviolent action, in which conspicuous protests encourage more people to participate and open repression against protesters causes a backlash against the regime. Studying these events using 
nonviolence theory can be a fruitful exercise, but our aim here is instead to draw attention to the value of studying events where nonviolent action was less prominent or less effective. In the case of the repressive Suharto regime, the 1965-1966 massacres and the 1975 invasion and occupation of East Timor offer opportunities for probing the dynamics of nonviolent action.

Studying prominent action no doubt will remain the centrepiece of the study of nonviolent action, but this needs to be supplemented by much more attention to periods and occasions where there are relatively low levels of action and to examining the key factors that, if somehow developed, could make a difference. The 1998 protests in Indonesia show what sort of people's action was possible, and throw into relief the relative lack of such effective opposition at other times. Likewise, the 1999 protests in Australia against killing in East Timor show what sort of people's action was possible outside of Indonesia, and throw into relief the relative lack of this sort of effective opposition at other times, notably during the 1965-1966 massacres and during and immediately after the 1975 invasion of East Timor.

In examining nonviolent action against Indonesian repression, we have focussed on political jiu-jitsu. In the toppling of Suharto, this occurred most obviously following the killing of students at Trisakti University by Indonesian troops, an act that triggered much greater opposition. But this powerful effect probably would not have occurred but for a range of preconditions: the student protest itself, earlier protests leading up to it, the prior preparation by activists and their development of nonviolent discipline, the wider mobilisation of opposition in Indonesia and the economic and political factors that encouraged open expression of dissent. The entire process appears like a model case study in the dynamics of nonviolent action, although the resignation of Suharto inhibited a wider social transformation. It is worth noting that actors outside Indonesia did not play a large role in the process.

In the 1965-1966 massacres, political jiu-jitsu was not effectively mobilised to halt the killings. There was insufficient preparation for resistance inside Indonesia and insufficient organisation to build on the resistance that did occur. Outside Indonesia, governments and populations were not triggered into action by the massacres.

In the 1975 invasion of East Timor, political jiu-jitsu was not effectively mobilised because the guerrilla resistance overshadowed the role of nonviolent action. Furthermore, communication outside the country was limited, reducing prospects for international mobilisation of resistance.

Both the 1965-1966 massacres and the case of East Timor point to an important factor in the effectiveness of political jiu-jitsu: the presence of a potentially sympathetic audience with access to information. In particular, third party audiences need to know about what is happening and be potentially concerned. In the case of the 1965-1966 massacres, reporting was limited and the dominant anti-communist mind-set limited concern. In the case of East Timor, communication out of the country was limited and governments were not inclined to be concerned.

When examining nonviolent action, there are many other aspects that are worthy of examination, such as the role of divisions among elite groups[56] or the availability of communication technology. [57] Our aim here, though, is less to point to particular factors in the success or failure of nonviolent action, but rather to show that examining cases where nonviolent action has a low profile or is not very effective has the potential for providing insights about nonviolent action. In both a case where nonviolent action was high profile and effective and in two cases where it was low profile and much less effective, we find that the effective triggering of political jiu-jitsu is crucial to success and a failure to trigger political jiu-jitsu helps explain lack of success. More specifically, in the toppling of Suharto, political jiu-jitsu was a key to success of nonviolent action, whereas in the 1965-1966 massacres and East Timor from 1975, lack of success can be attributed, in part, to a failure to trigger political jiu-jitsu. 
It is precisely because the standard conclusion -- that political jiu-jitsu is a key factor in the success of nonviolent action -- can be reached via the cases of low-profile resistance that shows that insights about the dynamics of nonviolent action can be obtained from these sorts of cases. Note that while studying high-profile, successful cases provides insight into what makes nonviolent action successful, studying lower-profile, relatively unsuccessful cases is more likely to provide insight into what prevents or inhibits success of nonviolent action. While these two types of insight are closely linked, they are not identical. Specifically, we found that studying less successful cases highlighted the importance of nonviolent action and repression being visible to potentially sympathetic audiences, a point that can easily be missed when nonviolent action has a higher profile and thus communication is less problematic.

There are enormous numbers of cases of lower profile nonviolent resistance available for study, offering a wealth of material for learning that has largely been untapped. In the case of Indonesia, examples of lower profile or less-than-fully-effective nonviolent action include movements for autonomy or independence in West Irian, Aceh and other provinces, workers' struggles against exploitative employers (national and transnational), efforts to resist religious oppression and indigenous people's struggles against development projects. While it is impossible to specify in advance what precisely can be learned by studying such cases, possibilities include factors in effective preparation for struggle, barriers to building nonviolent discipline, the ways violence inhibits the effectiveness of political jiu-jitsu, and strategies by oppressors to counter nonviolent mobilisation. There may be less inspiration in studying cases when resistance appears unsuccessful, but the possibility of additional insights makes the effort worthwhile.

\section{Acknowledgments}

We benefited from comments by Thomas Weber and two anonymous referees. This research was supported by the Australian Research Council.

\section{Footnotes}

1. For example, see Robert Cooney and Helen Michalowski (eds.), The Power of the People: Active Nonviolence in the United States (Philadelphia: New Society Press, 1987); Ralph E. Crow, Philip Grant and Saad E. Ibrahim (eds), Arab Nonviolent Political Struggle in the Middle East (Boulder: Lynne Rienner, 1990); M. K. Gandhi, An Autobiography or the Story of My Experiments with Truth (Ahmedabad: Navajivan, 1927); Pam McAllister, The River of Courage: Generations of Women's Resistance and Action (Philadelphia: New Society Press, 1991); Philip McManus and Gerald Schlabach (eds), Relentless Persistence: Nonviolent Action in Latin America (Philadelphia: New Society Press, 1991).

2. Thomas Weber, On the Salt March: The Historiography of Gandhi's March to Dandi (New Delhi: HarperCollins, 1997).

3. Patricia Parkman, Nonviolent Insurrection in El Salvador: The Fall of Maximiliano Hernández Martínez (Tucson: University of Arizona Press, 1988). For more cases, see Patricia Parkman, Insurrectionary Civic Strikes in Latin America 1931-1961 (Cambridge, MA: Albert Einstein Institution, 1990).

4. Souad R. Dajani, Eyes Without Country: Searching for a Palestinian Strategy of Liberation (Philadelphia: Temple University Press, 1994); Andrew Rigby, Living the Intifada (London: Zed Books, 1991). 
5. Stephen Zunes, 'The Role of Non-violent Action in the Downfall of Apartheid,' Journal of Modern African Studies, 37, 1 (1999), pp. 137-169.

6. This is carried out in exemplary form by Peter Ackerman and Christopher Kruegler, Strategic Nonviolent Conflict: The Dynamics of People Power in the Twentieth Century (Westport, CT: Praeger, 1994).

7. Gene Sharp, The Politics of Nonviolent Action (Boston: Porter Sargent, 1973), pp. 40-41.

8. D. J. Goodspeed, The Conspirators: A Study of the Coup d'État (London: Macmillan, 1962).

9. The mixing of such purposes is also found in other fields, notably the study of military operations.

10. For example, see Roland Bleiker, Popular Dissent, Human Agency and Global Politics

(Cambridge: Cambridge University Press, 2000); Joan V. Bondurant, Conquest of Violence: The Gandhian Philosophy of Conflict (Princeton: Princeton University Press, 1958); Robert J. Burrowes, The Strategic Theory of Nonviolent Defense: A Gandhian Approach (Albany, NY: State University of New York Press, 1995).

11. Richard B. Gregg, The Power of Nonviolence (New York: Schocken, [1935] 1966), pp. 43-51.

12. Gregg, The Power of Nonviolence, p. 46.

13. Sharp, The Politics of Nonviolent Action; Gene Sharp, Gandhi as a Political Strategist (Boston: Porter Sargent, 1979); Gene Sharp, Social Power and Political Freedom (Boston: Porter Sargent, 1980).

14. Sharp, The Politics of Nonviolent Action, pp. 449-814.

15. Sharp, The Politics of Nonviolent Action, p. 657.

16. Useful collections on these events are given in Edward Aspinall, Herb Feith and Gerry van Klinken (eds), The Last Days of President Suharto (Melbourne: Monash Asia Institute, Monash University, 1999); Geoff Forrester and R. J. May (eds), The Fall of Soeharto (Bathurst: Crawford House, 1998). See also Marcus Mietzner, 'From Soeharto to Habibie: The Indonesian Armed Forces and Political Islam During the Transition', in Geoff Forrester (ed), Post-Soeharto Indonesia: Renewal or Chaos? (Bathurst: Crawford House Publishing, 1999), pp. 65-102.

17. Ed Aspinall, 'Opposition and Elite Conflict in the Fall of Soeharto', in Forrester and May, The Fall of Soeharto, pp. 130-153, at pp. 131-132.

18. Richard J. Barnet and Ronald Muller, Global Reach: The Power of the Multinational Corporations (London: Jonathan Cape, 1975), p. 79.

19. Kevin Evans, 'Economic Update', in Forrester, Post-Soeharto Indonesia: Renewal or Chaos?, pp. 105-127.

20. Geoffrey Forrester, 'Introduction', in Forrester and May, The Fall of Soeharto, pp. 1-23, at pp. 17-18.

21. Ikrar Nusa Bhakti, 'Trends in Indonesian Student Movements in 1998', in Forrester and May, The Fall of Soeharto, pp. 167-178. 
22. Forrester, 'Introduction', p. 21.

23. Susan Berfield and Dewi Loveard, 'Ten Days that Shook Indonesia', Asiaweek (24 July 1998).

24. While Suharto was the primary target, there was also a faction fight in the military, which split into Wiranto and Probowo camps, with the Navy and Air Force distancing themselves from the rest of the armed forces and the police becoming autonomous. On military machinations, see Mietzner, 'From Soeharto to Habibie'.

25. Suzanne Charlé, '"Banning is Banned!"', The Nation, 267, 15 (5 October 1998), pp. 15-19, at p. 17.

26. Charlé, "'Banning is Banned!"', p. 18.

27. David L. Marcus, 'Indonesia Revolt Was Not Driven', in Aspinall et al., The Last Days of President Suharto, pp. 73-75.

28. Charlé, "'Banning is Banned!"', p. 15.

29. The Alliance of Independent Journalists was set up in opposition to the government-sponsored Union of Indonesian Journalists (PWI). See Murray Seeger, 'Press Suppression in Indonesia', Nieman Reports, 19, 1 (Spring 1995), p. 44.

30. Sometimes the regime blamed labour leaders for rioting against ethnic groups. See 'Labor Round-Up', Multinational Monitor, 15, 9 (September 1994), p. 4

31. For a concise summaries, see Malcolm Caldwell (ed.), Ten Years' Military Terror in Indonesia (Nottingham: Spokesman, 1975), pp. 13-17; Noam Chomsky and Edward S. Herman, The Political Economy of Human Rights, Volume 1: The Washington Connection and Third World Fascism (Montréal: Black Rose Books, 1979), pp. 205-217.

32. We try to avoid constructions in which a country is identified with its government, e.g. 'The US had never been pleased.' This form of metonymy is especially inappropriate when discussing nonviolent action, which often pits citizens against their government or its agents. Even our own constructions are shorthands for more accurate but complex formulations, such as 'US government' really meaning something like 'US dominant foreign policy elites.'

33. Responsibility for the coup has been much debated. Suharto and his allies have consistently attributed it to the PKI in order to justify their pogrom. Given that the PKI was totally unprepared for action, many analysts believe the coup was an internal military matter. Yet others think that Suharto knew about the plans and used the coup to get rid of rivals. See for example Humphrey McQueen, 'How Suharto Won Power', Independent Monthly (September 1990), pp. 24-29.

34. On the role of the CIA and US policy makers in Suharto's rise to power, see Peter Dale Scott, 'Exporting Military-Economic Development: America and the Overthrow of Sukarno, 1965-67', in Caldwell, Ten Years' Military Terror in Indonesia, pp. 209-263.

35. Barbara Harff and Ted Robert Gurr, 'Victims of the State: Genocides, Politicides and Group Repression from 1945 to 1995', in Albert J. Jongman (ed), Contemporary Genocides: Causes, Cases, Consequences (Leiden: Projecten Interdisciplinair Onderzoek naar de Oorzaken van Mensenrechtenschendingen, 1996), pp. 33-58.

36. For an account of the systematic torture and imprisonment of suspected communists, and of underground attempts to reorganise, see Carmel Budiardjo, Surviving Indonesia's Gulag: A Western 
Woman Tells Her Story (London: Cassell, 1996).

37. Marian Wilkinson, 'Hidden Holocaust', Sydney Morning Herald (10 July 1999), pp. 1s, 4s-5s; David Jenkins, 'The Silent Watchers', Sydney Morning Herald (12 July 1999), p. 11.

38. New York Times, 6 July 1966, quoted in Chomsky and Herman, The Political Economy of Human Rights, p. 217

39. Chomsky and Herman, The Political Economy of Human Rights, p. 205.

40. Sources include Carmel Budiardjo and Liem Soei Liong, The War Against East Timor (London: Zed Books, 1984); Peter Carey and G. Carter Bentley (eds), East Timor at the Crossroads: The Forging of a Nation (London: Cassell, 1995); James Dunn, Timor: A People Betrayed (Brisbane: Jacaranda, 1983); Jill Jolliffe, East Timor: Nationalism and Colonialism (Brisbane: University of Queensland Press, 1978); Arnold Kohen, From the Place of the Dead: The Epic Struggles of Bishop Belo of East Timor (New York: St. Martin's Press, 1999); Arnold Kohen and John Taylor, An Act of Genocide: Indonesia's Invasion of East Timor (London: TAPOL, 1979); John Pilger, Distant Voices (London: Vintage, 1994), pp. 231-323; Constâncio Pinto and Matthew Jardine, East Timor's Unfinished Struggle: Inside the Timorese Resistance (Boston: South End Press, 1997); John G. Taylor, Indonesia's Forgotten War: The Hidden History of East Timor (London: Zed Books, 1991).

41. Budiardjo and Liong, The War Against East Timor; Paulino Gama, 'The War in the Hills, 197585: A Fretilin Commander Remembers', in Carey and Bentley, East Timor at the Crossroads, pp. 97105; Kohen and Taylor, An Act of Genocide; Pinto and Jardine, East Timor's Unfinished Struggle. There is a theory that the Indonesian military 'allowed' Fretilin to survive in the hills in order to blood new soldiers in counter-insurgency. Some 10,000 to 20,000 Indonesian troops died in East Timor between 1975 and 1998.

42. Ed Ayres, 'The Costs and Benefits of War,' World Watch, 8, 1 (January-February 1995), p. 9.

43. Chomsky and Herman, The Political Economy of Human Rights, pp. 129-204; Kohen and Taylor, An Act of Genocide; Pilger, Distant Voices.

44. Budiardjo and Liong, The War Against East Timor, p. 9.

45. Gough Whitlam, The Whitlam Government, 1972-1975 (Melbourne: Penguin, 1985), pp. 102119.

46. Richard Walsh and George Munster, Secrets of State (Sydney: Angus \& Robertson, 1982), pp. 54-55.

47. The slaughter of guerrillas and civilians alike was largely undertaken with arms from Western countries, including Australia, Britain and the US. Militaries from these countries also provided training. See for example Pilger, Distant Voices, pp. 301-311.

48. Vanessa Baird, 'Bringing the Blood Back to British Aerospace', New Internationalist (March 1994), p. 21.

49. John Pilger, 'In a Liverpool Court Next Week, Four Women who Disarmed a Warplane Headed for Indonesia will Raise the Issue of our right to Stop Genocide', New Statesman and Society (19 July 1996), p. 23.

50. Denis Freney, A Map of Days: Life on the Left (Melbourne: Heinemann, 1991), p. 348. 
Political Jiu-Jitsu Against Indonesian Repression: Studying Lower Profile Nonviole... Page 16 of 16

51. Freney, A Map of Days, pp. 357-373.

52. Freney, A Map of Days, p. 363.

53. Chisako M. Fukuda, 'Peace through Nonviolent Action: The East Timorese Resistance Movement's Strategy for Engagement', Pacifica Review, 12, 1 (2000), pp. 16-31.

54. Pinto and Jardine, East Timor's Unfinished Struggle, pp. 188-199.

55. Kohen, From the Place of the Dead, pp. 160-187; Pilger, Distant Voices, p. 236.

56. Kurt Schock, 'People Power and Political Opportunities: Social Movement Mobilization and Outcomes in the Philippines and Burma', Social Problems, 46, 3 (August 1999), pp. 355-375.

57. Brian Martin, 'Communication Technology and Nonviolent Action', Media Development, 43, 2 (1996), pp. 3-9. 